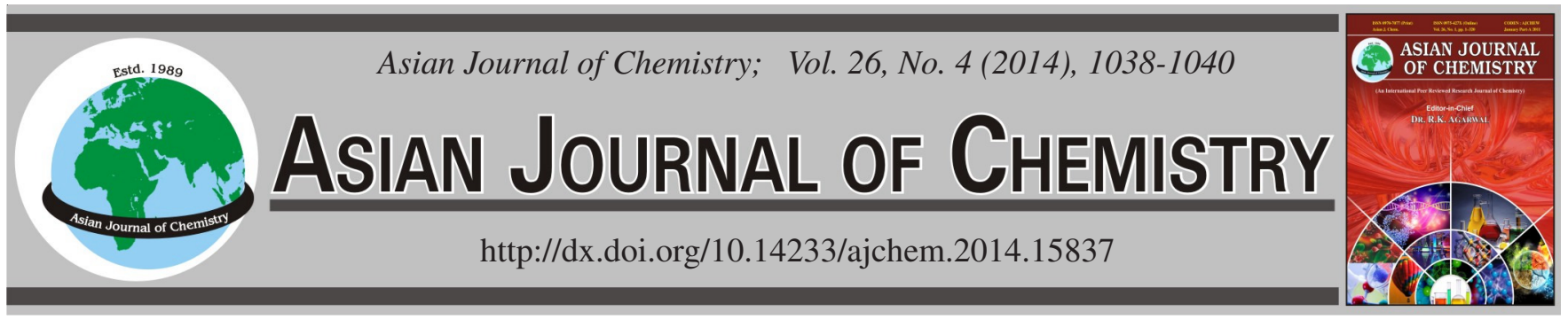

\title{
Determination of Forty-Six Elements in Different Organs of Orychophragmus violaceus in Agricultural Farm
}

\author{
Weidong CAO ${ }^{1,2, *}$, Yukui RuI ${ }^{3}$ and Xuguang $\mathrm{Li}^{3}$
}

${ }^{1}$ Key Laboratory of Plant Nutrition and Fertilizer, Ministry of Agriculture of the P.R. China/Institute of Agricultural Resources and Regional Planning, Chinese Academy of Agricultural Sciences, Beijing 100081, P.R. China

${ }^{2}$ Qinghai Academy of Agricultural and Forestry, Qinghai University, Xining 810016, P.R. China

${ }^{3}$ College of Resources and Environmental Sciences, China Agricultural University, Beijing 100193, P.R. China

*Corresponding author: Tel: +86 15652190727, E-mail: caoweidong@ caas.cn

Received: 28 May 2013;

Accepted: 21 August 2013;

Published online: 15 February 2014;

AJC-14694

\begin{abstract}
Orychophragmus violaceus has been used for food, oil, health care, feed and ornamental horticulture, but its elements components were less studied. The elemental composition in different organs of Orychophragmus violaceus were determined to provide technical support for its agricultural application. The results showed that (1) the contents of most nutrition elements in leaf and flower were higher than those in root, which proved that Orychophragmus violaceus is a good plant for green manure and feed, (2) the metal elements aluminium and lead were the highest in flowers of Orychophragmus violaceus; $\mathrm{Ti}, \mathrm{Cr}, \mathrm{Ni}, \mathrm{As}, \mathrm{Sn}$ and $\mathrm{Tl}$ were the highest in leaf of Orychophragmus violaceus; cadmium was the highest in root of Orychophragmus violaceus, which proved that Orychophragmus violaceus can be used for phytoremediation of soils contaminated by heavy metals except cadmium, and (3) the content of rare earth elements were generally low in Orychophragmus violaceus.
\end{abstract}

Keywords: Orychophragmus violaceus, Heavy metals, Trace beneficial elements, Rare earth elements.

\section{INTRODUCTION}

Orychophragmus violaceus is a biennial herbaceous plants belonging to cruciferae, which is a good plant for food, oil, health care, feed and ornamental horticulture. Orychophragmus violaceus has high economic value, ornamental value and broad developing prospect ${ }^{1}$.

Previous studies have shown that sowing Orychophragmus violaceus after the harvest of spring maize in North China, Orychophragmus violaceus can overwinter safely rapidly grow and cover ground after reviving and reached full bloom in April, when it is tender, juicy and high yield, can used as green manure to provide nutrients for the next crop after maize ${ }^{2}$. Previous research on Orychophragmus violaceus is limited to the oil ${ }^{3}$, feed grass ${ }^{4}$, flowers ${ }^{5}$, its nutrient characteristics and effects of the green manure were little understood.

The elements components of Orychophragmus violaceus were less studied, which requires to study its various elements in detail. In this paper, the macroelements, secondary elements, heavy metals, trace beneficial elements and rare earth elements in different organs of Orychophragmus violaceus were determined, which will provide technical support for the agricultural application of Orychophragmus violaceus.

\section{EXPERIMENTAL}

Orychophragmus violaceus were collected from Langfang city of Hebei Province, China Academy of Agricultural Sciences experimental base. The whole plant and its flowers were showed as Figs. 1 and 2.

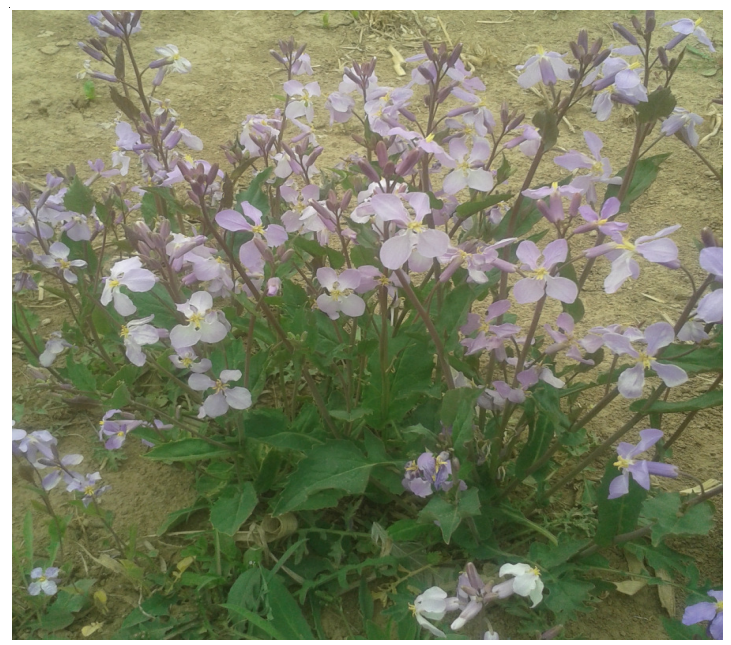

Fig. 1. Orychophragmus violaceus in corn field 


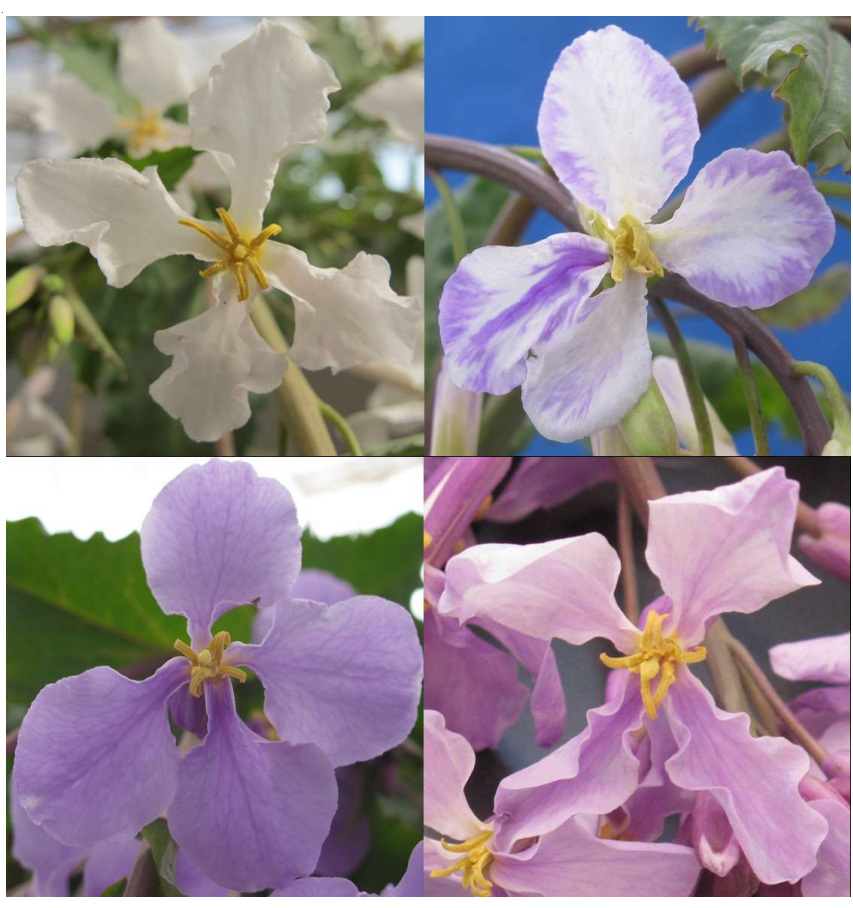

Fig. 2. Flowers of Orychophragmus violaceus

The flower, leaf and root were separated, washed with deionized water. Grinding, digesting and detecting by ICP-MS. The parameters of ICP-MS were referred to Rui et al. ${ }^{6}$ method.

\section{RESULTS AND DISCUSSION}

Concentration of macroelements in different organs of Orychophragmus violaceus: Orychophragmus violaceus contained many kinds of macroelements, the descending order of macroelements is $\mathrm{K}>\mathrm{Ca}>\mathrm{P}>\mathrm{Mg}>\mathrm{Si}>\mathrm{Na}>\mathrm{B}$. The results showed that $\mathrm{Ca}, \mathrm{Na}, \mathrm{B}$ and $\mathrm{Mg}$ had the highest concentration in leaf; K, P and Si were the highest in flower, all detected macroelements wer the lowest in root (Table-1).

\section{TABLE-1}

CONTENTS OF MACROELEMENTS IN DIFFERENT ORGANS OF Orychophragmus violaceus $\left(\mu \mathrm{g} \mathrm{g}^{-1}\right)$

\begin{tabular}{cccc}
\hline Elements & Flower & Root & Leaf \\
\hline $\mathrm{B}$ & 19.69 & 12.01 & 22.05 \\
$\mathrm{Na}$ & 210.53 & 199.25 & 240.61 \\
$\mathrm{Mg}$ & 1204.99 & 380.79 & 1271.30 \\
$\mathrm{Si}$ & 322.58 & 239.72 & 207.08 \\
$\mathrm{P}$ & 3864.03 & 1747.57 & 2613.93 \\
$\mathrm{~K}$ & 12911.21 & 8075.82 & 10043.72 \\
$\mathrm{Ca}$ & 4750.79 & 3121.87 & 12834.32 \\
\hline
\end{tabular}

Concentration of secondary elements in different organs of Orychophragmus violaceus: Secondary elements are important for plant growth and development. The descending order of secondary elements in leaf of Orychophragmus violaceus is $\mathrm{Fe}>\mathrm{Sr}>\mathrm{Mn}>\mathrm{Zn}>\mathrm{Br}>\mathrm{Cu}>\mathrm{I}$; the descending order of secondary elements in root of Orychophragmus violaceus is $\mathrm{Fe}>\mathrm{Sr}>\mathrm{Zn}>\mathrm{Mn}>\mathrm{Cu}>\mathrm{Br}>\mathrm{I}$; and the descending order of secondary elements in flower of Orychophragmus violace $\mathrm{s}$ is $\mathrm{Fe}>\mathrm{Zn}>\mathrm{Mn}>\mathrm{Sr}>\mathrm{Cu}>\mathrm{Br}>$ I. Most secondary elements in root were lower than leaf and flower, which is similar to macroelements (Table-2).
TABLE-2

CONTENTS OF SECONDARY ELEMENTS IN DIFFERENT ORGANS OF Orychophragmus violaceus $\left(\mu \mathrm{g} \mathrm{g}^{-1}\right)$

\begin{tabular}{cccc}
\hline Elements & Flower $\left(\mu \mathrm{g} \mathrm{g}^{-1}\right)$ & Root $\left(\mu \mathrm{g} \mathrm{g}^{-1}\right)$ & Leaf $\left(\mu \mathrm{g} \mathrm{g}^{-1}\right)$ \\
\hline $\mathrm{Mn}$ & 32.64 & 16.31 & 86.86 \\
$\mathrm{Fe}$ & 234.52 & 123.06 & 1776.91 \\
$\mathrm{Cu}$ & 8.56 & 3.34 & 4.98 \\
$\mathrm{Zn}$ & 44.10 & 16.65 & 28.75 \\
$\mathrm{Br}$ & 2.69 & 2.02 & 7.86 \\
$\mathrm{Sr}$ & 23.13 & 35.13 & 88.83 \\
$\mathrm{I}$ & 0.95 & 1.90 & 1.30 \\
\hline
\end{tabular}

Concentration of heavy metals in different organs of Orychophragmus violaceus: Heavy metals reached to microgram level in Orychophragmus violaceus are Al, Ti, Cr, Ni and $\mathrm{Pb}$. The heavy metal elements $\mathrm{Al}$ and $\mathrm{Pb}$ were the highest in flowers; Ti, Cr, Ni, As, Sn and Tl were the highest in leaf; $\mathrm{Cd}$ was the highest in root. Other heavy metals were all lower than $0.1 \mu \mathrm{g} \mathrm{g}^{-1}$ (Table-3). The above results show that Orychophragmus violaceus is a high quality plant for phytoremediation of soils contaminated by heavy metals.

\begin{tabular}{cccc}
\multicolumn{4}{c}{ TABLE-3 } \\
\multicolumn{4}{c}{ CONTENTS OF HEAVY METALS IN DIFFERENT } \\
& ORGANS OF Orychophragmus violaceus \\
\hline Elements & Flower $\left(\mu \mathrm{g} \mathrm{g}^{-1}\right)$ & Root $\left(\mu \mathrm{g} \mathrm{g}^{-1}\right)$ & Leaf $\left(\mu \mathrm{g} \mathrm{g}^{-1}\right)$ \\
\hline $\mathrm{Al}$ & 170.03 & 131.51 & 95.07 \\
$\mathrm{Ti}$ & 15.38 & 12.30 & 43.33 \\
$\mathrm{Cr}$ & 2.14 & 2.22 & 221.68 \\
$\mathrm{Ni}$ & 1.66 & 0.90 & 18.70 \\
\hline Elements & Flower $\left(\mathrm{ng} \mathrm{g}^{-1}\right)$ & Root $\left(\mathrm{ng} \mathrm{g}^{-1}\right)$ & Leaf $\left(\mathrm{ng} \mathrm{g}^{-1}\right)$ \\
\hline $\mathrm{As}$ & 186.91 & 134.73 & 235.72 \\
$\mathrm{Ag}$ & 6.28 & 38.92 & 8.64 \\
$\mathrm{Cd}$ & 108.49 & 378.24 & 236.92 \\
$\mathrm{Sn}$ & 69.47 & 26.40 & 71.05 \\
$\mathrm{Sb}$ & 34.83 & 10.24 & 20.16 \\
$\mathrm{Hg}$ & 0.00 & 0.00 & 0.00 \\
$\mathrm{Tl}$ & 27.98 & 12.97 & 45.37 \\
$\mathrm{~Pb}$ & 1357.44 & 184.57 & 679.31 \\
\hline
\end{tabular}

Concentration of trace beneficial elements in different organs of Orychophragmus violaceus: Molybdenum is the highest beneficial trace elements in Orychophragmus violaceus. Other beneficial trace elements were in turn $\mathrm{Co}, \mathrm{Li}$ and Se. These four elements in the leaves was the highest, followed by the flowers and the lowest in the root (Table-4).

\begin{tabular}{cccc}
\multicolumn{5}{c}{ TABLE-4 } \\
\multicolumn{4}{c}{ CONTENTS OF TRACE BENEFICIAL ELEMENTS IN } \\
DIFFERENT ORGANS OF & Orychophragmus & violaceus $\left(\mathrm{ng} \mathrm{g}^{-1}\right)$ \\
\hline Elements & Flower & Root & Leaf \\
\hline Li & 301.48 & 198.00 & 414.79 \\
Co & 374.19 & 173.65 & 578.49 \\
Se & 5.52 & Nil & 50.89 \\
Mo & 884.66 & 575.79 & 1476.48 \\
\hline
\end{tabular}

Concentration of rare earths elements in different organs of Orychophragmus violaceus: The content of rare earth elements were generally low in Orychophragmus violaceus, which is relative to the concentration in soil and little usage of rare earth fertilizer. Four highest rare earth elements are $\mathrm{Ce}, \mathrm{La}, \mathrm{Sc}$ and $\mathrm{Nd}$ (Table-5). 
TABLE-5

CONTENTS OF RARE EARTHS ELEMENTS IN DIFFERENT ORGANS OF Orychophragmus violaceus ( $\mathrm{ng} \mathrm{g}^{-1}$ )

\begin{tabular}{cccc}
\hline Elements & Flower & Root & Leaf \\
\hline $\mathrm{La}$ & 247.81 & 135.18 & 113.78 \\
$\mathrm{Ce}$ & 716.60 & 419.89 & 343.49 \\
$\mathrm{Pr}$ & 51.77 & 28.45 & 24.24 \\
$\mathrm{Nd}$ & 185.00 & 102.41 & 87.13 \\
$\mathrm{Sm}$ & 28.55 & 12.97 & 23.04 \\
$\mathrm{Eu}$ & 9.71 & 7.51 & 7.92 \\
$\mathrm{Gd}$ & 33.12 & 17.07 & 21.60 \\
$\mathrm{~Tb}$ & 4.57 & 2.05 & 2.16 \\
$\mathrm{Dy}$ & 22.27 & 10.92 & 11.52 \\
$\mathrm{Ho}$ & 3.43 & 2.73 & 2.16 \\
$\mathrm{Er}$ & 8.56 & 6.83 & 5.04 \\
$\mathrm{Tm}$ & 1.14 & 0.68 & 0.72 \\
$\mathrm{Yb}$ & 6.85 & 6.14 & 2.16 \\
$\mathrm{Lu}$ & 1.14 & Null & Null \\
$\mathrm{Y}$ & 88.88 & 46.88 & 42.25 \\
$\mathrm{Sc}$ & 232.78 & 158.17 & 179.07 \\
\hline
\end{tabular}

\section{Conclusions}

- Most nutrition elements in leaf and flower were higher than root, which proved that Orychophragmus violaceus is a good plant for green manure and feed.
- Orychophragmus violaceus can be used for phytoremediation of soils contaminated by heavy metals except cadmium.

\section{ACKNOWLEDGEMENTS}

The project was supported by (1) Special Fund for Agroscientific Research in the Public Interest (201103005) and (2) Science and Technology Innovation Project of Chinese Academy of Agricultural Sciences. The authors also thank Ms. Ouyang Li and Prof. Wang Jingyu (Peiking University, China) for their assistance in detection.

\section{REFERENCES}

1. L. Zhang, H. Qin, M. Wang and S. Dai, Chinese Biodiversity, 13, 535 (2005).

2. L. Jia, C. Wei-Dong, R. Xiang-Nong, J. Qiang and L. Jin-Feng, Soil Fertilizer Sci. China, 1, 78 (2010).

3. L.V. Zhongjin, Chinese Wild Plants, 3, 1 (1992).

4. L. Peng and B. Huang, Acta Pratacult. Sci., 7, 53 (1998).

5. P. Shengwei, Z. Qixing, Z. Hao and S. Rongguang, Acta Sci. Circumst., 29, 786 (2009).

6. R. Yukui, Z. Hongxing, G. Jing, H. Kunlun, Z. Benzhong and L. Yunbo, Agro Food Ind. Hi-Tech, 17, 35 (2006). 